JURNAL EINSTEIN
Jurnal Hasil Penelitian Bindang Fisika
$\begin{gathered}\text { Available online http://jurnal.unimed.ac.id/2012/index.php/inpafi } \\ \text { e-issn: } 2407-747 x, p-i s s n ~ 2338-1981\end{gathered}$

\title{
SINTESIS DAN KARAKTERISASI NANO PARTIKEL SILIKA DARI ABU AMPAS TEBU SEBAGAIFILLER ALUMINIUM
}

\author{
Doli Bonardo Hasan dan Karya Sinulingga \\ Jurusan Fisika, Fakultas Matematika dan Ilmu Pengetahuan Alam, Universitas Negeri Medan, \\ Indonesia \\ hasanbonardo@gmail.com \\ Diterima April 2017; Disetujui Mei 2017; Dipublikasikan Juni 2017
}

\begin{abstract}
ABSTRAK
Sintesis dan karakterisasi nano partikel silika dari abu ampas tebu bertujuan untuk mengetahui hubungan antara variasi suhu pembakaran awal terhadap struktur morfologi, ukuran partikel dan kristalnya, fasa yang terbentuk serta kekuatan tarik campuran antara nanosilika terbaik dengan aluminium. Abu ampas tebu kemudian dibakar didalam furnace selama 2 jam dengan suhu divariasikan $300^{\circ} \mathrm{C}, 400^{\circ} \mathrm{C}, 500^{\circ} \mathrm{C}$ dan $600^{\circ} \mathrm{C}$. Selanjutnya sampel dimillingselama 4 jam dengan kecepatan $250 \mathrm{rpm}$. Nanosilika disintesis menggunakan metode kopresipitasi dengan larutan $\mathrm{HCl} 1$ $\mathrm{M}$ dan $\mathrm{NaOH} 1 \mathrm{M}$. Sedangkan metode pencampuran aluminium dengan nanosilika menggunakan metode metalurgi serbuk. Dari analisis XRD, keempat sampel memiliki fasa silika dan garam sebagai fasa pengotor. Kenaikan suhu pembakaran awal, menyebabkan menurunnya ukuran kristal yaituyang terbesar $78,43 \mathrm{~nm}\left(300^{\circ} \mathrm{C}\right)$, dan yang terkecil $34,72 \mathrm{~nm}\left(600^{\circ} \mathrm{C}\right)$. Dari hasil PSA menunjukkan ukuran partikel nanosilika terbesar $245,5 \mathrm{~nm}\left(300^{\circ} \mathrm{C}\right)$, dan terkecil $38,9 \mathrm{~nm}\left(600^{\circ} \mathrm{C}\right)$. Dari analisis SEM, diperoleh keempat morfologi nanosilika menunjukkan butiran yang kurang rapat. Dari pengujian UTM, diperoleh modulus young campuran aluminium dengan nanosilika sebesar 1769,4 Mpa.
\end{abstract}

Kata Kunci: Abu Ampas Tebu, Suhu Pembakaran Awal, Metode Kopresipitasi, Nanosilika

\section{PENDAHULUAN}

Silika $\left(\mathrm{SiO}_{2}\right)$ merupakan salah satu bahan yang termasuk ke dalam golongan oksida yang memiliki potensi pemanfaatan pada berbagai aplikasi. Selain dapat digunakan sebagai bahan baku industri gelas dan kaca, silika juga dapat digunakan sebagai bahan baku pembuatan sel surya (Munasir, dkk.2013). Selain itu silika juga digunakan sebagai piranti semikonduktor, pembuatan keramik dan lain-lain.Silika bisa didapatkan dari pasir silika yang jumlahnya melimpah di Indonesia atau dari limbah penghancuran gelas dan kaca juga dari bahan organik seperti abu sekam padi dan abu ampas tebu (Munasir, dkk. 2013).Sintesis silika memerlukan perlakuan khusus untuk sampai pada skala nano, yaitumenggunakan beberapa metode seperti metode sol-gel process, metode gas phaseprocess,metode kopresipitasi, metode emulsion techniques, dan metode plasma spraying \& fogingprocess (polimerisasi silika terlarut menjadi organo silika). Kopresipitasi merupakan metodeyang menjanjikan karena prosesnya menggunakan temperatur rendah 
sehingga waktu yangdibutuhkan relatif lebih singkat, yaitu \pm 12 jam (Yusuf, M.dkk. 2014).

Hariharan. V dan Sivakumar G, (2013) pernah meneliti mengenai cara sintesis nano partikel silika dari ampas tebu, dalam penelitian ini ampas tebu diproses dengan metode pengabuan kemudian nano partikel silika didalam kandungan abu ampas tebu disintesis menggunakan metode kopresipitasi. Hasil penelitian menggunakan XRD diperoleh nano partikel silika yang amorphous, ketika diamati melalui alat mikrografi SEM nano partikel silika ini berbentuk seperti bola, homogen dan berkelompok. Nano partikel silika memiliki beberapa sifat diantaranya: luas permukaan besar, ketahanan panas yang baik, kekuatan mekanik yang tinggi dan inert sehingga digunakan sebagai prekursor katalis, adsorben dan filler pada bahan komposit. Penggunaan nano partikel silika dari abu ampas tebu sebagai filler pada matriks dapat meningkatkan kekuatan mekanik pada campuran tersebut (Gowri Shankar, 2014)

Gowri Shankar (2014) pernah melakukan penelitian terkait pembuatan komposit Aluminium dengan silika $\left(\mathrm{SiO}_{2}\right)$ dimana penelitian ini memvariasikan silika dengan variasi $0 \%, 3 \%$ dan $6 \%$ sebagai filler matriks aluminium dengan metode vortex. Hasil penelitian ini diperoleh nilai kekerasan untuk variasi $0 \%, 3 \%$ dan $6 \%$ berturut-turut sebesar $1726 \mathrm{~Pa}, 1804 \mathrm{~Pa}$ dan $1873 \mathrm{~Pa}$. Penelitian ini untuk memecahkan masalah yang sering ditemui pada material dalam penggunaan dengan tuntutan mekanik tinggi. Sintesis dan karakterisasi nano partikel silika dari abu ampas tebu bertujuan untuk mengetahui hubungan antara variasi suhu pembakaran awal terhadap struktur morfologi, ukuran partikel dan kristalnya, fasa yang terbentuk serta kekuatan tarik campuran antara nanosilika terbaik dengan aluminium.

\section{METODE PENELITIAN}

Dalam penelitian ini menggunakan bahan abu ampas tebu yang didapatkan dari Pabrik Gula Kwala Madu Di Kabupaten Stabat, Sumatera Utara. Sintesis silika menggunakan metode kopresipitasi. Pembakaran awal abu ampas tebu divariasikan dengan suhu $300^{\circ} \mathrm{C}, 400$ ${ }^{\circ} \mathrm{C}, 500{ }^{\circ} \mathrm{C}$ dan $600{ }^{\circ} \mathrm{C}$. Metode kopresipitasi dilakukan menggunakan larutan asam $\mathrm{HCl} 1 \mathrm{M}$ dan sebagai larutan pengendap digunakan $\mathrm{NaOH}$ 1 M. Nano partikel silika yang diperoleh dikarakterisasi menggunakan XRD (X-ray diffratometer) type $P A N$ analytical Empyrean untuk mengetahui fasa yang terbentuk, PSA (Particle Size Analyzers) untuk mengetahui ukuran partikel dan distribusi ukuran partikel, SEM/EDS (scanning electron microscopy-energy dispersive spectroscopy) merkZeiss EVO MA 10untuk mengamati morfologi partikel secara kualitatif dan komposisi unsur didalamnya. Pencampuran antara aluminium dengan nanosilika dilakukan menggunakan metode metalurgi serbuk dan dikarakterisasi menggunakan UTM (Universal Testing Machine) untuk mengetahui kekuatan tarik campuran tersebut.

\section{HASILDAN PEMBAHASAN}

\section{Analisis Fasa Dan Ukuran Kristal}

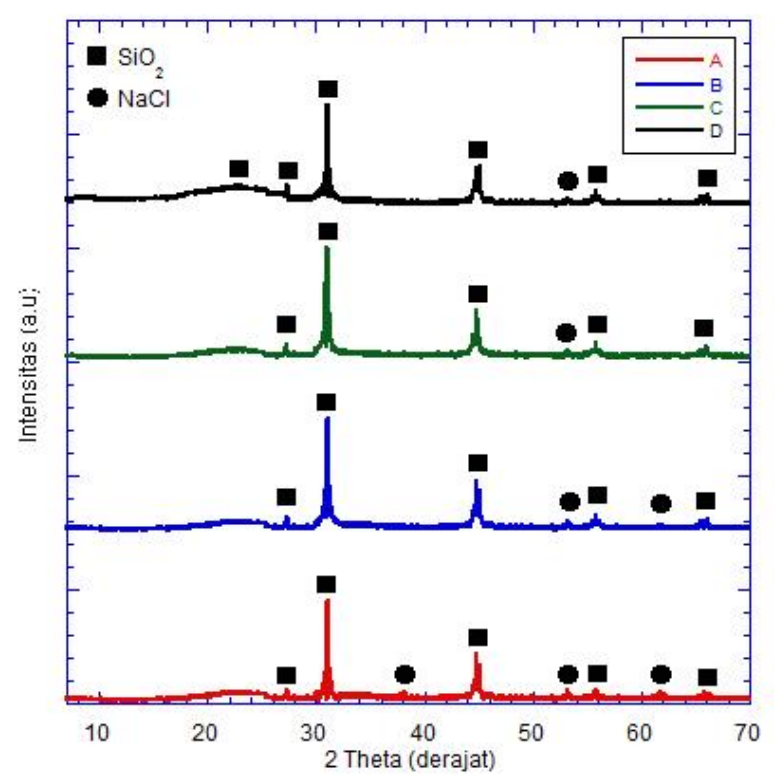

Gambar1.Poladifraksi nano partikel silika (A) suhu $300^{\circ} \mathrm{C}$, (B) suhu $400^{\circ} \mathrm{C}$, (C) suhu $500^{\circ} \mathrm{C}$ dan $(\mathrm{D})$ suhu $600^{\circ} \mathrm{C}$

Pada pola difraksi gambar 1 (a) fasa $\mathrm{NaCl}$ pada sampel memiliki 3 puncak dengan intensitas tertentu, tetapi saat suhu pembakaran awal dinaikkan menjadi $400^{\circ} \mathrm{C}$ fasa $\mathrm{NaCl}$ yang 
terbentuk berkurang menjadi 2 puncak dan intensitas tertinggi pada fasa $\mathrm{NaCl}$ berkurang dari sampel sebelumnya sebesar 24 cts terlihat pada pola difraksi gambar 1 (b). Pada pola difraksi sampel dengan suhu $500^{\circ} \mathrm{C}$ yaitu pada gambar 1 (c) fasa $\mathrm{NaCl}$ semakin berkurang terlihat dari jumlah puncak menjadi hanya satu, selain itu puncak fasa $\mathrm{NaCl}$ bergeser sebesar $0,08^{\circ}$ ke arah kiri tetapi intensitas meningkat sebesar 10 cst dari sampel sebelumnya. Kemudian pada sampel suhu pembakaran $600^{\circ} \mathrm{C}$, terlihat pada pola difraksi gambar 1 (d) fasa $\mathrm{NaCl}$ masih memiliki satu puncak tetapi intensitasnya meningkat sebesar 185. Hal ini menunjukkan pada suhu $600^{\circ} \mathrm{C}$ semua fasa yang terkandung di dalam nanosilika cenderung meningkat.

Pada pola difraksi gambar 1 (a) fasa silika yang terbentuk memiliki 5 puncak dengan intensitas tertentu, dan pada pola difraksi gambar 1 (b) fasa silika yang terbentuk tetap memiliki 5 puncak tetapi terjadi peningkatan intensitas tertinggi sebesar $100 \mathrm{cts}$. Pada sampel berikutnya yang dibakar pada suhu $500^{\circ} \mathrm{C}$, fasa silika yang terbentuk tetap memiliki 5 puncak tetapi sudut theta pada puncak tertinggi bergeser sebesar $0,08^{\circ} \mathrm{ke}$ arah kiri dengan besar intensitas yang sama terlihat pada pola difraksi gambar 1 (c). Sedangkan pada pola difraksi gambar 1 (d), terdapat puncak baru yang menunjukkan fasa silika sehingga jumlah puncak pada fasa silika menjadi 6 puncak. Puncak tertinggi bergeser pada 2 theta sebesar $0,04^{\circ}$ dan puncak yang baru berada pada sudut $(2 \theta) 22,6^{\circ}$.

Sistem kristal yang terbentuk pada sampel nanosilika suhu pembakaran awal $300^{\circ} \mathrm{C}, 400^{\circ} \mathrm{C}$, $500^{\circ} \mathrm{C}$ memiliki sistem yang berbeda. Melalui analisis menggunakan free software Match!, sistem kristal pada sampel nanosilika suhu $300^{\circ} \mathrm{C}$ yaitu kubik dengan parameter kisi $\mathrm{a}=\mathrm{b}=\mathrm{c}=$ 5,7425 A. Sistem kristal pada sampel nanosilika suhu $400^{\circ} \mathrm{C}$ yaitu trigonal dengan parameter kisi $\mathrm{a}=\mathrm{b}=\mathrm{d}=5,0837 \AA$ dan $\mathrm{c}=5,4955 \AA$, kemudian sistem kristal pada sampel nanosilika suhu $500^{\circ} \mathrm{C}$ yaitu hexagonal dengan parameter kisi $\mathrm{a}=\mathrm{b}=\mathrm{d}$ $=5,0520 \AA$ dan $\mathrm{c}=8,2700 \AA$, sedangkan sistem kristal pada sampel nanosilika suhu $600^{\circ} \mathrm{C}$ yaitu tetragonal dengan parameter kisi $\mathrm{a}=\mathrm{b}=6,8719$ $\AA$ dan $\mathrm{c}=6,8165 \AA$.

Difraksi sinar $\mathrm{X}$ juga dapat digunakan untuk menentukan ukuran kristal (crystallite size) dengan fase tertentu dengan menggunakan modifikasi persamaan Deybe Schrrer berikut ini.

$$
\mathrm{D}=\frac{k \lambda}{e^{\text {Intersep }}}
$$

Tabel 1. menyajikan perbandingan ukuran kristal sampel nanosilika suhu pembakaran awal $300^{\circ} \mathrm{C}, 400^{\circ} \mathrm{C}, 500^{\circ} \mathrm{C}$ dan $600^{\circ} \mathrm{C}$.Pada Tabel 1 terlihat bahwa ukuran kristal sampel Nano Partikel Silika berkurang seiring dengan meningkatnya suhu pembakaran awal yang diberikan. Hal ini menandakan bahwa penambahan suhu pembakaran awal dapat memperkecil ukuran kristal pada partikel didalam sampel.

Tabel 1. Perbandingan Ukuran Kristal Sampel Nanosilika

\begin{tabular}{ccc}
\hline No & Sampel & $\begin{array}{c}\text { Ukuran Kristal } \\
\text { (nm) }\end{array}$ \\
\hline $\mathbf{1}$ & Nanosilika $\left(300^{\circ} \mathrm{C}\right)$ & 78,43 \\
\hline $\mathbf{2}$ & Nanosilika $\left(400^{\circ} \mathrm{C}\right)$ & 48,92 \\
\hline $\mathbf{3}$ & Nanosilika $\left(500^{\circ} \mathrm{C}\right)$ & 46,39 \\
\hline $\mathbf{4}$ & Nanosilika $\left(600^{\circ} \mathrm{C}\right)$ & 34,72 \\
\hline
\end{tabular}

\section{Analisis Ukuran Partikel Dan Distribusinya}

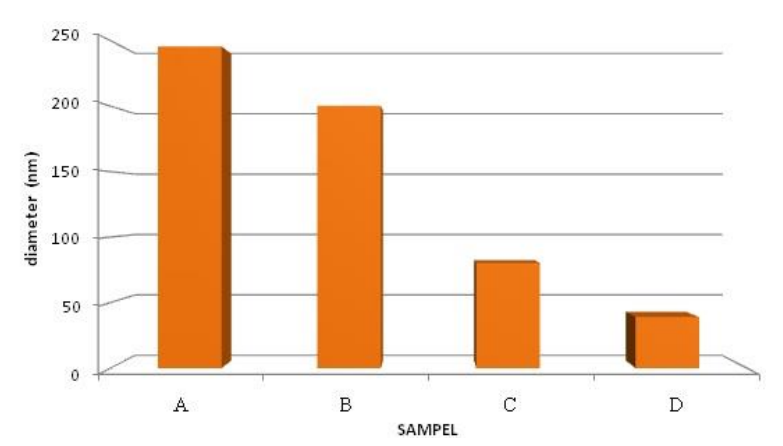

Gambar2. Grafik Perbandingan Ukuran Partikel (A) Nanosilika $300^{\circ} \mathrm{C}$, (B) Nanosilika $400^{\circ} \mathrm{C},(\mathrm{C})$ Nanosilika $500^{\circ} \mathrm{C}$ dan (D) Nanosilika $600^{\circ} \mathrm{C}$.

Dari gambar 2 tersebut terlihat bahwa bertambahnya suhu pada pembakaran awal nano partikel silika menyebabkan ukuran partikel cenderung menurun. Hal ini dapat terjadi karena silika memiliki kecenderungan kelarutan yang bersifat positif. Artinya, saat suhu 
meningkat, kelarutan akan meningkat. Pada kondisi kelarutan yang tinggi akan menghasilkan mobilitas ionik yang tinggi, viskositas yang rendah dan konsentrasi ion yang lebih banyak yang akan mengakibatkan terpisahnya aglomerat sehingga akan menghasilkan ukuran partikel lebih kecil (Wibowo, A. 2015), maka suatu aglomerat partikel dapat berpisah satu sama lain pada suhu tertentu yang menyebabkan menurunnya ukuran partikel. Namun saat suhu ditingkatkan kembali, ukuran partikel kembali meningkat dengan kristalinitas yang lebih baik (Wibowo, A. 2015). Nilai Polydispersity Index pada suhu $300^{\circ} \mathrm{C}, 400^{\circ} \mathrm{C}, 500{ }^{\circ} \mathrm{C}$ dan suhu $600^{\circ} \mathrm{C}$ dapat dilihat secara berturut-turut pada gambar 3 dan 4 .

Dispersi yang homogen memiliki nilai PDI mendekati nol sementara nilai PDI yang lebih besar dari 0,3 menyatakan dispersi yang heterogen. Selain itu polidispersiti index (PDI) merupakan parameter yang mendefinisikan distribusi ukuran partikel. Nilai PDI antara 0,01 hingga $0,5-0,7$ merupakan partikel yang homogen. Partikel yang memiliki nilai PDI $>0,7$ menandakan distribusi ukuran yang lebar dan tidak seragam (heterogen). Nilai PDI yang rendah menandakan banyaknya dispersi mono dalam larutan. Untuk mengukur PDI dapat diamati dengan menggunakan media pendispersi, dan media pendispersi nanosilika berupa air (Wibowo. A, 2015). Berikut distribusi ukuran partikel pada nanosilika $\left(300^{\circ} \mathrm{C}\right)$ dan nanosilika $\left(400^{\circ} \mathrm{C}\right)$.

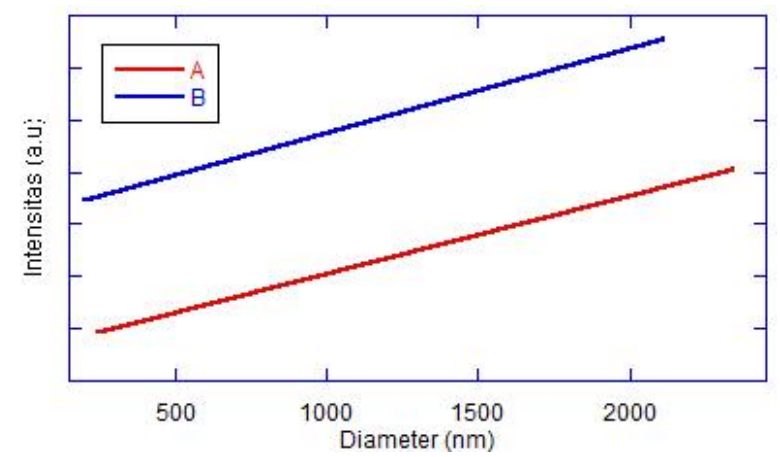

Gambar 3. Grafik Perbandingan PDI (A) Nanosilika $\quad 300^{\circ} \mathrm{C}, \quad \operatorname{dan}(\mathrm{B})$ Nanosilika $400^{\circ} \mathrm{C}$.

Berdasarkan gambar 3, garis yang cukup lebar pada grafik menunjukkan perbedaan ukuran yang sangat besar pada sampel. Perbedaan tersebut ditandai dengan nilai antara dua skala yang cukup besar sehingga dapat dipastikan terdapat banyak ketigakseragaman ukuran partikel didalam sampel. Melalui hasil pengujian juga dapat dilihat bahwa sebaran ukuran partikel yang ditunjukkan nilai PDI pada sampel nanosilika suhu $300^{\circ} \mathrm{C}$ sebesar 1,38 dan sampel nanosilika $400^{\circ} \mathrm{C}$ memiliki nilai PDI 1,00 . Kedua sampel memiliki nilai PDI diatas 0,7, yang menandakan distribusi ukuran partikel yang lebar dan tidak seragam (heterogen). Kemudian untuk distribusi ukuran partikel pada nanosilika $\left(500^{\circ} \mathrm{C}\right)$ dan nanosilika $\left(600^{\circ} \mathrm{C}\right)$ disajikan pada grafik berikut.

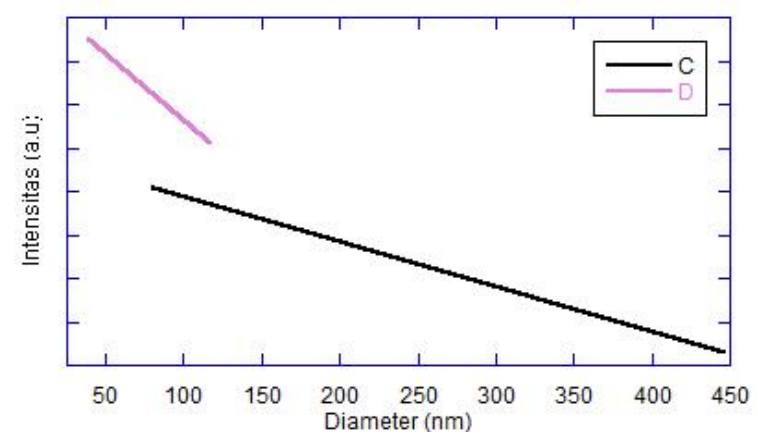

Gambar 4. Grafik Perbandingan PDI (C)

Nanosilika $500^{\circ} \mathrm{C}$, dan $\quad$ (D) Nanosilika $600^{\circ} \mathrm{C}$.

Berdasarkan gambar 4, garis pada grafik tidak terlalu lebar. Menurut hasil pengujian, sampel nanosilika suhu $500^{\circ} \mathrm{C}$ memiliki nilai PDI sebesar 0,42 dan sampel nanosilika $600^{\circ} \mathrm{C}$ memiliki nilai PDI sebesar 0,14. Karena kedua sampel tersebut memiliki nilai PDI dibawah 0,7 maka hal ini menandakan distribusi ukuran partikel dapat dikatakan homogen. Dari keempat grafik tersebut, dapat terlihat bahwa dengan meningkatnya suhu pembakaran awal, maka nilai PDI cenderung menurun. Menurunnya nilai PDI menandakan semakin seragamnya ukuran partikel, hal ini sesuai dengan penelitian yang dilakukan oleh Wibowo, A. (2015), bahwa semakin tinggi suhu pembakaran awal maka menyebabkan semakin rendah nilai PDI pada sampel. 
Pengamatan Morfologi Dan Komposisi Unsur Nano Partikel Silika
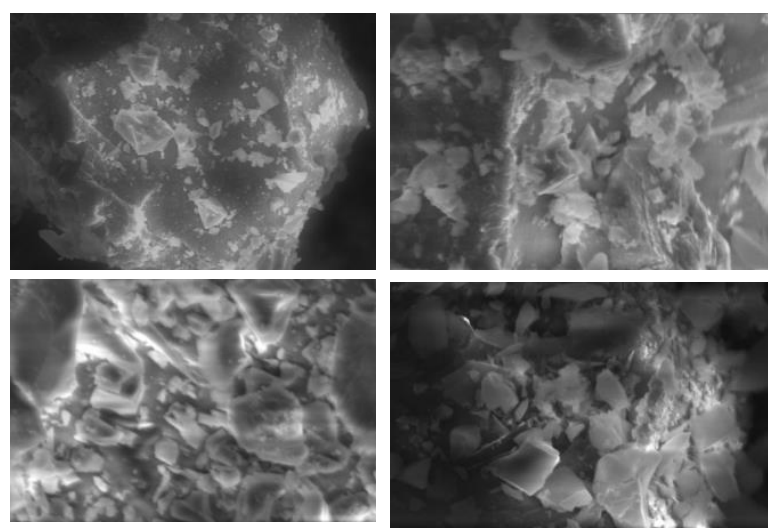

Gambar 5. Morfologi sampel nano partikel silika pembesaran 3000x (a) nanosilika $300^{\circ} \mathrm{C}$, nanosilika $400^{\circ} \mathrm{C}$,(c) nanosilika $500{ }^{\circ} \mathrm{C}$ dan (e) nanosilika 600 ${ }^{\circ} \mathrm{C}$.

Dari keempat gambar morfologi pada sampel nano partikel silika, diperoleh hubungan antara suhu pembakaran awal dengan kualitas morfologi sampel. Semakin tinggi suhu pembakaran awal pada sampel, maka semakin baik bentuk dan sebaran bentuk butiran pada sampel. Selain itu rongga antara butiran semakin rapat dan semakin sedikit seiring bertambahnya suhu pembakaran awal pada sampel.

Komposisi unsur pada sampel juga dapat dilihat melalui analisis $E D X$ yang berada di satu unit SEM. Pengujian komposisi dilakukan pada sampel nano partikel silika suhu pembakaran awal $300^{\circ} \mathrm{C}$ dan $600^{\circ} \mathrm{C}$. Hal ini dilakukan karena menurut Hariharan, et all (2013), semakin tinggi suhu pembakaran awal pada abu ampas tebu, maka semakin tinggi kandungan silika didalamnya dan semakin menurunkan kadar pengotor selain silika didalam abu ampas tebu. Berikut hasil pengamatan komposisi unsur pada sampel nanosilika $\left(300^{\circ} \mathrm{C}\right)$.

Tabel 2. Komposisi Unsur Pada Nanosilika $\left(300^{\circ} \mathrm{C}\right)$

\begin{tabular}{|c|c|c|}
\hline Elemen & Atom C. (at. \%) & Norm C. (wt \%) \\
\hline $\mathrm{Si}$ & 36,24 & 48,28 \\
\hline $\mathrm{O}$ & 45,62 & 39,00 \\
\hline $\mathrm{Na}$ & 14,72 & 9,19 \\
\hline $\mathrm{Cl}$ & 3,42 & 3,54 \\
\hline
\end{tabular}

Berdasarkan tabel 2, terlihat bahwa pada partikel nanosilika terdapat unsur $\mathrm{Si}, \mathrm{O}, \mathrm{Na}$ dan Cl. Namun unsur Si dan O merupakan unsur dengan kandungan terbesar yaitu $\mathrm{Si}$ sebesar $48,28 \%$ (wt) dan $\mathrm{O} 39,00 \%$ (wt) sedangkan kandungan atom terbesar yaitu O sebesar $45,62 \%$ $\begin{array}{lllll}\text { (at) dan } & \mathrm{Si} & 36,24 \% & \text { (at). Sesuai analisis }\end{array}$ menggunakan xrd yang menunjukkan adanya fasa impurities (pengotor) dari sampel nanosilika $\left(300^{\circ} \mathrm{C}\right)$ yaitu fasa $\mathrm{NaCl}$. Hal ini terlihat pada pengamatan menggunakan edx, bahwa kandungan fasa tersebut terbentuk dari reaksi antara unsur $\mathrm{Na}$ (natrium) dan $\mathrm{Cl}$ (klorin). Kemudian sampel nanosilika $\left(600^{\circ} \mathrm{C}\right)$ juga diamati kandungan unsur didalamnya, berikut hasil pengujian eds pada sampel nanosilika suhu pembakaran $600^{\circ} \mathrm{C}$

Tabel 3. Komposisi Unsur Pada Nanosilika $\left(300^{\circ} \mathrm{C}\right)$

\begin{tabular}{|c|c|c|}
\hline Elemen & Atom C. (at. \%) & Norm C. (wt \%) \\
\hline $\mathrm{Si}$ & 57,39 & 42,95 \\
\hline $\mathrm{O}$ & 27,04 & 35,19 \\
\hline $\mathrm{Na}$ & 8,31 & 13,99 \\
\hline $\mathrm{Cl}$ & 7,26 & 7,87 \\
\hline
\end{tabular}

Berdasarkan tabel 3, terlihat bahwa pada partikel nanosilika juga terdapat unsur $\mathrm{Si}, \mathrm{O}, \mathrm{Na}$ dan Cl. Namun unsur Si dan O merupakan unsur dengan kandungan terbesar yaitu $\mathrm{Si}$ sebesar $42,95 \%$ (wt) dan O 35,19\% (wt) sedangkan kandungan atom terbesar yaitu $\mathrm{Si}$ sebesar $57,39 \%$ (at) dan O 27,04\% (at). Selain kedua unsur itu, terdapat unsur pengotor berupa unsur $\mathrm{Na}$ dan $\mathrm{Cl}$, tetapi kandungannya sudah mulai berkurang. Sehingga dapat disimpulkan bahwa kandungan unsur $\mathrm{Si}$ dan $\mathrm{O}$ yang membentuk silika akan semakin meningkat seiring bertambahnya suhu pembakaran awal pada sampel. Selain itu berdasarkan kedua tabel antara nanosilika suhu $300^{\circ} \mathrm{C}$ dan $600^{\circ} \mathrm{C}$, dapat dibandingkan bahwa terlihat juga unsur pengotor $\mathrm{Na}$ dan $\mathrm{Cl}$ mengalami pengurangan jumlah atom dan fraksi beratnya sehingga semakin tinggi suhu pembakaran awal maka semakin berkurang kandungan unsur pengotor pada sampel nano partikel silika. 


\section{Analisis Modulus Young Campuran Aluminium Dengan Nanosilika}

Pada pengujian ini sampel diuji sesuai standar praparasi sampel uji ASTM E8/E8M-09. Dari hasil perhitungan kekuatan tarik pada sampeldengan menggunakan persamaan : $\sigma=\frac{F}{A_{0}}$. dimana $A_{0}$ adalah luas sampel. Kemudian dapat dihitung juga modulus young yaitu ukuran suatu bahan yang diartikan ketahan material tersebut terhadap deformasi elastik (Ginting. E.M, et al, 2014). Menentukan modulus young pada sampel diperoleh menggunakan persamaan $=\frac{\sigma}{\varepsilon}$, dimana $\varepsilon$ adalah regangan yang diperoleh pada data hasil uji tarik. Melalui persamaan diatas, diperoleh kurva modulus young terhadap regangan seperti berikut.

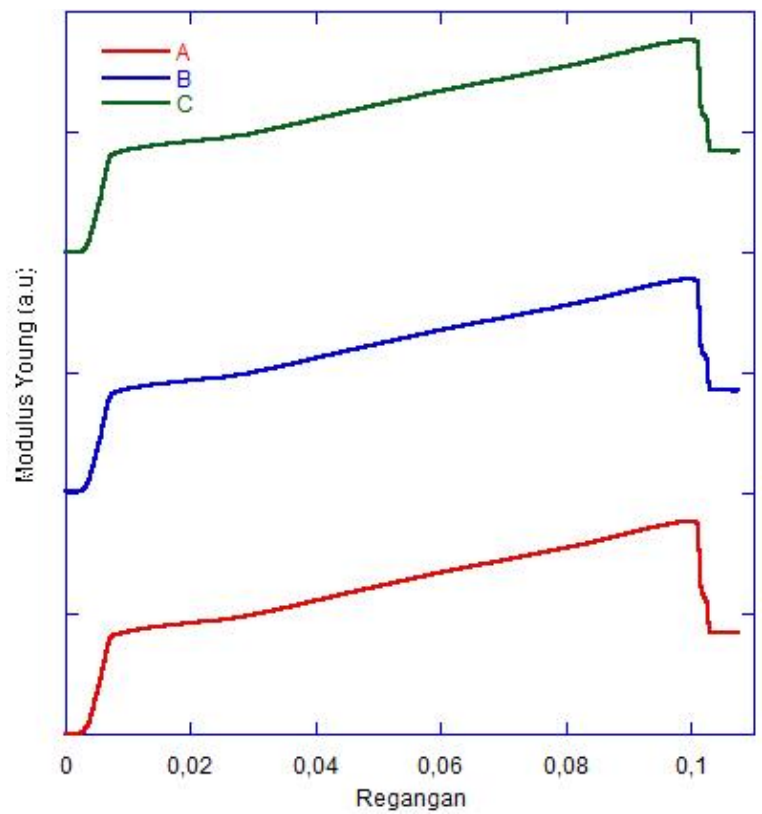

Gambar 6. Grafik Perbandingan Hubungan Modulus Young Dengan Regangan Pada Sampel Campuran AlNanosilika

Berdasarkan gambar 6, terlihat bahwa modulus young maksimum rata-rata pada sampel campuran alumunium dengan nanosilika adalah sebesar 1769,433 $\mathrm{Mpa}$ atau 1,769,43 $\mathrm{kN} / \mathrm{mm}^{2}$. Menurut penelitian Usman A.M, et al (2014) modulus young alumunium murni sekitar 1600-1700 Mpa. Hal ini menunjukkan adanya kenaikan modulus young karena adanya pengisi nanosilika pada campuran dengan alumunium. Berikut tabel modulus young ketiga sampel yang dimaksud.
Tabel 4. Modulus Young Campuran Aluminium Dengan Nanosilika

\begin{tabular}{|c|c|c|c|}
\hline Sampel & $\sigma_{\text {maks }}(\mathrm{Mpa})$ & $\varepsilon_{\text {maks }}(\%)$ & $\mathrm{E}(\mathrm{MPa})$ \\
\hline 1 & 176,61 & 10 & 1766,1 \\
\hline 2 & 177,86 & 10 & 1778,6 \\
\hline 3 & 176,36 & 10 & 17636 \\
\hline
\end{tabular}

Pada tabel 4.6, memperlihatkan modulus young maksimum pada setiap sampel campuran aluminium dengan nanosilika. Regangan yang diperoleh disetiap sampel cenderung sama karena setelah sampel mengalami perpatah, terjadi penambahan panjang $20 \mathrm{~mm}$ sehingga regangan maksimum pada sampel yaitu sebesar $10 \%$. Perbedaan modulus young maksimum antara alumunium murni dengan campuran alumunium dan nanosilika menandakan bahwa ketahanan material campuran alumunium dengan nanosilika terhadap deformasi elastik lebih tinggi dibandingkan alumunium murni. Karena semakin besar modulus young pada material maka semakin kecil regangan elastik yang dihasilkan akibat pemberian tegangan (Ginting, E.M, et al 2014).

\section{KESIMPULAN DAN SARAN}

Adapun kesimpulan dari penelitian ini adalah: (1) Morfologi setiap sampel mengalami perbedaan, diantaranya semakin bertambahnya suhu pembakaran awal maka rongga (jarak) antar butir didalam sampel semakin menyempit (rapat), ukuran butir dan sebaran ukuran butirnya cenderung semakin homogen dan bentuk butiran berubah menjadi kepingankepingan sedangkan Komposisi unsur yang terkandung pada sampel nanosilika $300^{\circ} \mathrm{C}$ yaitu unsur $\mathrm{Si}, \mathrm{O}, \mathrm{Na}$ dan $\mathrm{Cl}$ dengan jumlahnya berturut-turut 48,28\%, 39,00\%, 9,19\% dan $3,54 \%$ (wt). Sedangkan pada sampel nanosilika $600^{\circ} \mathrm{C}$ yaitu unsur $\mathrm{Si}$ mengalami penurunan menjadi 42,95\% dan O menjadi 35,19\% (wt). (2) Hasil analisa PSA menunjukkan ukuran partikel silika pada suhu pembakaran awal $300^{\circ} \mathrm{C}$ sebesar $245,5 \mathrm{~nm}$ dan semakin berkurang hingga menjadi $38,91 \mathrm{~nm}$ pada sampel nanosilika suhu $600^{\circ} \mathrm{C}$. Hal ini menandakan bahwa ukuran partikel silika semakin mengecil seiring bertambahnya suhu pembakaran awal pada abu 
ampas tebu. (3) Melalui analisa XRD, Seiring bertambahnya suhu, puncak-puncak pada kedua fasa didalam sampel mengalami perubahan jumlah. Puncak yang menunjukkan fasa garam mengalami pengurangan jumlah, sedangkan puncak yang menunjukkan fasa silikamengalami penambahan menjadi 6 puncak pada nano partikel silika $600^{\circ} \mathrm{C}$. (4) Suhu pembakaran awal juga mempengaruhi ukuran kristal pada nano partikel silika, hal ini ditandai dengan ukuran kristal pada nanosilika $300^{\circ} \mathrm{C}$ sebesar $78,43 \mathrm{~nm}$ dan mengalami penurunan ukuran kristal hingga ukuran 34,72 pada sampel nanosilika $600^{\circ} \mathrm{C}$. (5) Hasil pengujian tarik campuran aluminium dengan nanosilika menunjukkan kekuatan tarik maksimum pada sampel rata-rata sebesar 177 MPa atau $0,177 \mathrm{kN} / \mathrm{mm}^{2}$ sedangkan modulus young maksimum rata-rata sebesar 1769,433 MPa atau $1,76943 \mathrm{kN} / \mathrm{mm}^{2}$.

Untuk pengembangan penelitian ini, Penulis menyarankan agar suhu pembakaran awal perlu dicoba pada suhu $700^{\circ} \mathrm{C}$, dan $800^{\circ} \mathrm{C}$ karena akan semakin meningkatkan kuantitas dari silika dan meningkatkan derajat kristalinnya.

\section{DAFTAR PUSTAKA}

Ginting. E.M., Bukit. N., (2014), Karakterisasi Material, Medan, Unimed Press

Gowri. S.M. C., Jayashree P. K., U. Achuthakini, S. S Sharma, (2014), Effect Of Silicon Oxide ( $\mathrm{SiO}_{2}$ ) Reinforced Particles On Ageing Behavior Of Al-2024 Alloy, 5 (9)

Hariharan. V., Sivakumar. G., (2013), Studies On Synthesized Nanosilica Obtained From Bagasse Ash., ISSN : 0974-42905 (3), 1263-1266

Munasir, Widodo, Triwikantoro, Zainuri. M., Darminto, (2013), Perbandingan Massa Kalium Hidroksida Pada Ekstraksi $\mathrm{SiO}_{2}$ Orde Nano Berbasis Bahan Alam Pasir Kuarsa. Prosiding Seminar Nasional Sains Dan Pendidikan Sains VII UKSW

Wibowo. A, (2015), Sintesis Nanosilika Dari Abu Ketel Menggunakan Metode Hidrotermal Dengan Variasi Waktu Dan Suhu Proses, Skripsi, IPB

Yusuf. M., Suhendar. D., Hadisantoso. E.P, (2014), Studi Karakteristik Silika Gel Hasil
Sintesis Dari Abu Ampas Tebu Dengan Variasi Konsentrasi Asam Klorida, 3 (1) 